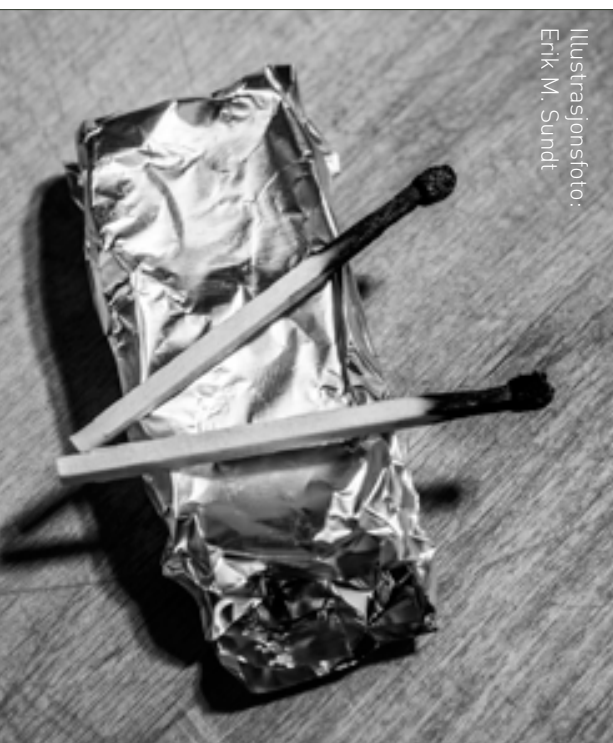

Bakgrunn: Bruk av rusmidler hos mennesker med alvorlig psykisk lidelse gir en $\emptyset$ kt risiko for voldsut$\varnothing v e l s e$. Spesielt bruk av flere rusmidler og bruk av amfetaminer og alkohol er assosiert med voldsatferd.

Hensikt: Denne studien undersøker sammenhengen mellom forskjellige rusmidler og vold mot andre hos en gruppe mannlige pasienter ( $N=146$ ) med alvorlige psykiske lidelser og gjentatte eller lengre innleggelser i psykiatrisk sykehus. Dette ble gjort ved å undersøke om det er en forhøyet voldsrisiko forbundet med ikke-paranoid og paranoid psykose,

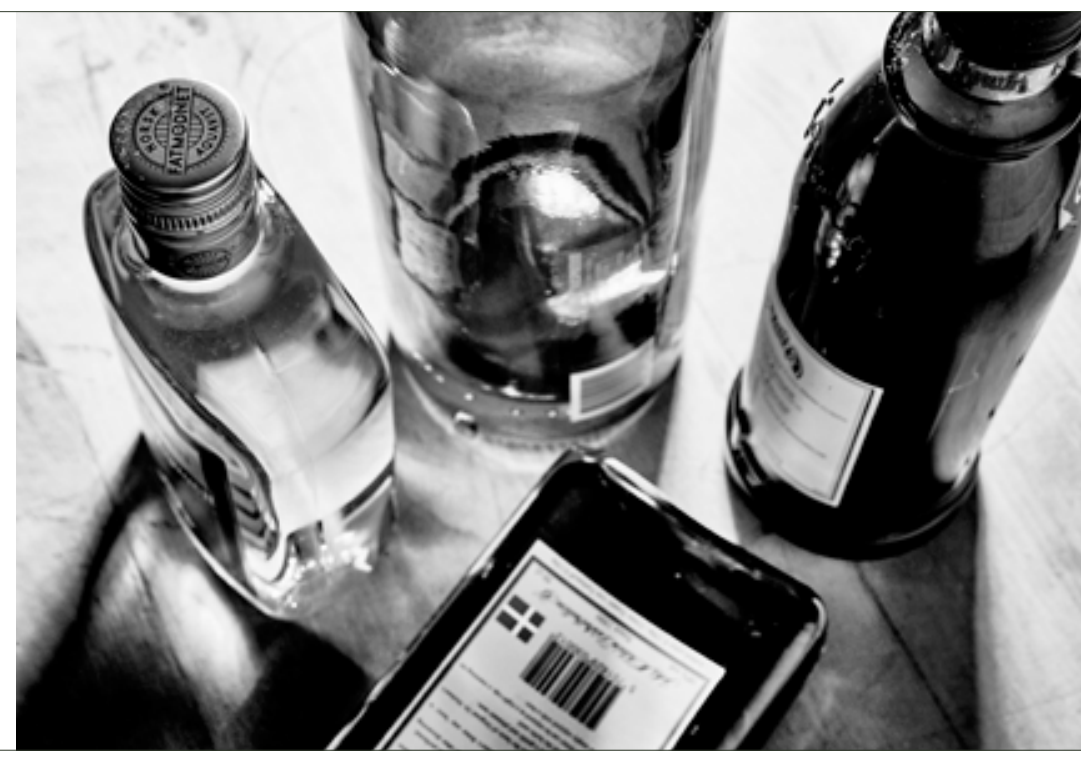

TCO-symptomer (Perceived Threat and Control Overridel og bruk av stimulanter, cannabis, opioider og alkohol, og om det finnes særskilte kombinasjoner av disse faktorene som $ø$ ker voldsrisiko

Metode: Forekomsten av rusbruk, vold, TCO-symptomer og diagnoser ble kartlagt med av en sjekkliste. Signifikante variabler fra bivariate analyser ble lagt inn stegvis i logistisk regresjonsanalyse, enkeltvis og parvis.

Resultater: Alkohol og cannabis var forbundet med en signifikant høyere risiko for voldsutøvelse, med oddsra- tioer (OR) på henholdsvis 6.4 og 6.7. Bruk av stimulanter predikerte ikke vold etter at effekten av cannabis ble kontrollert for. Av diagnoser og symptomer ga spesielt TCO-symptomet «å føle seg styrt av ytre krefter» en signifikant høyere risiko for voldsutøvelse (OR 5.8). Pasienter som brukte alkohol og cannabis hadde en signifikant høyere voldsforekomst hvis de også hadde TCO-symptomer.

Konklusjon: Undersøkelsen viste at bruk av alkohol og cannabis i kombinasjon med vrangforestillinger kan gi en markant høyere risiko for voldsut $\varnothing v e l s e$ hos mennesker med alvorlig psykisk lidelse.
Does use of specific substances increase risk of violent behaviour among men with severe mental disorders?

Background: Use of multiple substances and amphetamines increases risk of violent behaviour among individuals with severe mental disorders.

Objective: This study compares the importance of different drugs for violence risk in patients with severe mental disorders. This was done by examining (1) whether there is an elevated risk of violence associated with non-paranoid and paranoid psychosis, TCO symptoms and the use of stimulants, cannabis, opioids and alcohol, and (2) if there are specific combinations of these factors that increase the risk of violence.

Method: The incidence of substance use, violence, Perceived Threat and Control Override symptoms (TCO), and diagnoses were identified in a group of male patients $(N=146)$ with repeated or prolonged hospitalisation in a psychiatric hospital. Significant variables from the bivariate analyses were entered individually and in pairs in stepwise multivariate logistic regression analysis.

Results: Alcohol and cannabis were associated with a significantly higher risk of violent behaviour, with odds ratios (OR) of 6.4 and 6.7, respectively. Stimulant use was not a signi- ficant predictor of violence when the effect of cannabis was controlled for Among diagnoses and symptoms, the TCO symptom to feel controlled by external forces' significantly increased violence risk (OR 5.8). Introducing TCO in the regression analyses increased the OR for violence in patients with alcohol and cannabis use.

Conclusion: The combination of alcohol and cannabis use with the delusion that one's thoughts are controlled by forces beyond one's control, may significantly increase risk of violent behaviour in individuals with severe mental illness.

Keywords: severe mental illness, TCO, alcohol, cannabis, violence 


\section{Bruk av spesifikke rusmidler gir okt risiko for voldsutovelse hos menn med alvorlige psykiske lidelser}

Forfattere: Kristian Bachmann, Roar Fosse og Stål Bjørkly

\section{NøKKELORD}

- Psykisk lidelse

- Rus

- Alkohol

- Cannabis

- Vold

\section{INTRODUKSJON}

Befolkningsstudier har vist en noe større risiko for voldsutøvelse hos personer med alvorlige psykiske lidelser som schizofreni, andre psykoselidelser, bipolar lidelse og alvorlige personlighetsforstyrrelser (1-4). Basert på både forskning (5-8), kliniske erfaringer og medias framstilling av hendelser i samfunnet, er det økt oppmerksomhet og bekymring for vold særlig ved paranoide psykosetilstander. Selv om det bare er en liten andel pasienter som utøver vold i denne gruppen, så er det viktig å identifisere kjennetegn som er typiske for akkurat disse pasientene.

Enkelte av symptomene ved schizofreni og andre psykoselidelser ser ut til å øke risikoen for voldsutøvelse. Dette gjelder særlig såkalte TCO-symptomer (percieved threat and control override) $(6,9)$. Dette er vrangforestillinger om at andre vil skade en, at ens tanker eller følelser er styrt av ytre krefter, og at tanker er plassert i ens hode $(9,10)$. To metastudier fant at hallusinasjoner, vrangforestillinger og særlig TCO-symptomer kunne assosieres med vold hos personer med schizofreni og andre psykoselidelser $(2,7)$. Pasienter med vrangforestillinger som utløser sterkt emosjonelt ubehag, kan ha en høyere risiko for å utøve vold enn de med vrangforestillinger som ikke gir sterkt ubehag (8). Frykt, stress og bekymringer på grunn av vrangforestillinger kan altså være en sentral forklaringsfaktor (8).

Elbogen \& Johnson (3) vektlegger at det ikke er alvorlige psykiske lidelser i seg selv som predikerer voldsatferd, men heller andre faktorer som er assosiert med psykisk lidelse. Bruk av rusmidler er en slik faktor og øker risikoen for voldsutøvelse i befolkningen generelt. Spesielt gjelder dette alkohol, kokain og metamfetamin, men også cannabis $(11,12)$. Også for personer med alvorlig psykisk lidelse er rusmiddelbruk trukket frem som risikofaktor for voldsutøvelse, spesielt hos de med psykoselidelser $(9,13,14)$. Bruk av rusmidler sees hyppig hos mennesker med disse lidelsene (10). En nyere publisert studie fra Norge undersøkte risiko for voldsutøvelse hos mannlige pasienter med alvorlig psykisk lidelse som brukte rusmidler. (15). Studien viste at bruk av flere forskjellige rusmidler kunne ha en kraftig

\section{Hva tilfører artikkelen?}

Funnene i artikkelen tyder på at pasienter med alvorlig psykisk lidelse og skadelig bruk av cannabis og alkohol, har høyere risiko for voldsutøvelse hvis de også lider av ubehagelige vrangforestillinger.

\section{Mer om forfatterne:}

Kristian Bachmann er psykiatrisk sykepleier med master i helsefag. ansatt ved Molde Behandlingssenter som tilbyr spesialisert rusbehandling. Roar Fosse er forsker i klinikk for psykisk helse og rus, Vestre Viken HF. Stål Bjørkly er professor i klinisk psykologi, Avdeling for helse-og sosialfag, Høgskolen i Molde og forskningsveileder ved kompetansesenter for sikkerhets-, fengsels- og rettspsykiatri, Oslo universitetssykehus. Kontaktperson: kristian. bachmannahelse-mr.no. 
kumulativ effekt på risikoen for voldsutøvelse i pasientgruppen. Hos personer med alvorlig psykisk lidelse, men uten rusmiddelbruk synes imidlertid risikoen for voldsutøvelse ikke å være større enn i befolkningen for øvrig. Det er derfor grunner til å anta at økt voldsutøvelse ved psykose og annen alvorlig psykisk lidelse kan knyttes til bruk av rusmidler.

Man bør også være oppmerksom på at et komplekst samspill med flere faktorer enn bruk av rusmidler kan virke inn på voldsutøvelse hos mennesker med psykoselidelser. Det gjelder faktorer som tidligere voldshistorikk, atferdsavvik i brukte andre rusmidler som for eksempler stimulanter. Når det gjelder cannabis, fant en reviewstudie (17) at marihuana inntatt i moderate doser kan ha en nøytral eller dempende virkning på aggressiv atferd.

Oppsummert ser man at bruk av rusmidler kan være en betydelig risikofaktor for vold hos mennesker med alvorlig psykisk lidelse, gjerne i faser av lidelsen som kan føre til hospitalisering. Få tidligere studier har undersøkt sammenhengen mellom et bredt spekter av rusmidler og voldsutøvelse, eller hvordan dette interagerer med ulike diagnoser og spesifikke symptomer, særlig

\section{Vold var definert som fysisk vold utfort i samfunnet utenfor sykehus.}

barndom eller oppvekst (conduct disorder), lavere alder, mannlig kjønn, livskriser som samlivsbrudd og arbeidsløshet, å ha blitt utsatt for overgrep og vold (viktimisering), og høy paranoid beredskap (3,7,10). Douglas, Guy og Hart (2) fant i en metastudie at faktorer som antisosial personlighet eller psykopati, og tidlig debut med kriminalitet var større risikofaktorer for voldsutøvelse enn psykoselidelser.

Flere studier angir en sammenheng mellom bruk av (gjerne illegale) rusmidler og voldsutøvelse hos personer med alvorlig psykisk lidelse $(3,10,16)$. Ofte uten å spesifisere hvilke rusmidler det er snakk om. Blant spesifiserte rusmidler assosiert med vold finner man alkohol (16-18). Det er også antydet en sammenheng mellom sentralstimulerende stoffer og økt voldsatferd $(14,17)$. En studie (19) anga at opioidbruk er assosiert med vold, men med den begrensning at studiepopulasjonen også
TCO-symptomer. Dermed har man i liten grad undersøkt slike sammenhenger i multivariate design.

Vi ønsket å undersøke hvilke rusmidler som er assosiert med voldsutøvelse og betydningen av spesifikk diagnose eller spesielle psykosesymptomer alene eller i kombinasjon med rusmidler. Vi undersøkte dette i en gruppe mannlige pasienter med hyppige innleggelser i spesialisthelsetjenesten i psykisk helsevern med utgangspunkt $\mathrm{i}$ to forskningsspørsmål: 1. Er det en forhøyet voldsrisiko forbundet med ikkeparanoid og paranoid psykose, TCO-symptomer og bruk av forskjellige typer rusmidler (stimulanter, cannabis, opiater og alkohol)? 2. Finnes det særskilte kombinasjoner av disse faktorene som øker voldsrisikoen?

\section{METODE}

Problemstillingene ble undersøkt i perioden 2008-2011 i en gruppe mannlige pasienter $(\mathrm{n}=146)$ med gjentatte innleggelser i psykiatriske sengeposter i Vestre Viken HF i perioden 2008-2011. Eksklusjonskriterier var: kun rusdiagnose uten diagnose for psykisk lidelse, organisk hjerneskade, Tourettes syndrom, autisme og psykisk utviklingshemming. Gjennomsnittsalder i pasientgruppen var 40,6 år $(S D=13,0)$. Gjennomsnittlig antall innleggelser var 13,7 (SD=15,6). To fagpersoner brukte en sjekkliste til å gå gjennom informasjon om hver pasient i elektronisk pasientjournal for de fem siste årene. Femti av journalene ble tilfeldig valgt ut for å regne ut interrater reliabilitet målt med Cohens Kappa (k). Resultatene viste høy interrater reliabilitet.

\section{Forskningsetikk}

Innhenting av de data som ligger til grunn for studien er vurdert av REK til å være systematisk egenevaluering og utenfor deres mandat. Publikasjon basert på datasettet er godkjent per tilråding av Personvernombudet i Vestre Viken HF. Studien omhandler en sårbar gruppe mennesker, og forfatterne ønsker å vektlegge at funn og resultater $i$ vår studie ikke generelt må forstås som at mennesker med psykiske lidelser og bruk av rusmidler representerer en voldsrisiko. Denne registerstudien uten informert samtykke ivaretar ikke brukernes opplevelse og forståelse av de undersøkte sammenhengene. Studien berører heller ikke kjønnsaspekter i forhold til problemstillingene, da studien ikke inkluderte kvinner.

\section{Diagnoser}

ICD-10 diagnoser for psykisk lidelse og skadelig bruk av ett eller flere rusmidler ble hentet 
fra elektroniske pasientjournaler. Av de 146 deltakerne hadde 87 (59,6 prosent) en diagnose, 50 (34,2 prosent) hadde to diagnoser og ni $(6,2$ prosent) hadde tre. De med to eller flere diagnoser ble lagt inn i studien med hoveddiagnose. Hoveddiagnosene ble videre fordelt i fem overordnete kategorier: paranoid psykose $(n=41)$, andre psykoselidelser $(n=46)$, bipolar lidelse $(n=23)$, personlighetsforstyrrelser $(\mathrm{n}=23)$ og stemningslidelser $(n=34)$.

\section{Bruk av rusmidler}

Bruk av cannabis, alkohol, stimulanter og opioider ble definert som at minst ett av følgende kriterier var til stede: 1 ) ICD 10 rusdiagnose dokumentert gjennom pasientjournal. 2) Skåre over diagnostisk grenseverdi på strukturerte skjema: AUDIT (Alcohol use disorder identifications test) (20) eller DUDIT (Drug use disorders identification test) (21). 3) Annen informasjon i pasientjournal som kvalifiserte pasienten for en ICD-10 rusdiagnose. Sistnevnte inkluderte pågående rusbehandling ved institusjon, selvrapportert bruk av minst seks halvlitere $\varnothing l$ eller en halvliter sprit daglig over minst to uker, positiv på urinprøver for et rusmiddel over minst to uker, behandling for alkohol delirium eller selvrapportert bruk av stimulanter mer enn tre ganger ukentlig over en måned. Interrater-reliabiliteten for skåringen av rusmisbruk var høy, k=0,87 (p <0,001) mellom de to skårerne (15).

\section{TCO}

Forekomst av Perceived threat and control override symptomer ble kartlagt med tre spørsmål basert på Link og Stueve (10): 1) Har du opplevd at dine tanker/følelser er styrt av krefter utenfor din kontroll? 2) Har du opplevd å ha tanker plassert $i$ hodet som ikke er dine egne? og 3) Har du følt at andre mennesker vil skade deg? Interrater reliabiliteten for mål på TCOsymptomene var god, $\mathrm{k}=0,54$ ( $\mathrm{p}$ $<0,001)(15)$.

\section{Vold}

Vold var definert som fysisk vold utført i samfunnet utenfor sykehus. Dette ble operasjonalisert som knivstikking, målrettete slag eller spark, nedskalling, kasting av tunge gjenstander mot andre, voldtekt eller dommer for legemsbeskadigelse. Vold beskrevet i pasientjournalene var innrapportert fra forskjellige kilder: Pasienten selv, pårørende, fastleger og politi. De fleste deltakerne var også undersøkt med et strukturert skjema for vold, V-RISK-10 (22). Interrater-reliabiliteten for skåringen av voldsutøvelse var høy, $\mathrm{k}=0,87(\mathrm{p}<0,001)(15)$.

\section{Statistiske analyser}

Det ble utført krysstabulering mellom kategoriske variabler. Pearson's kji-kvadrat test ble brukt for å undersøke hvilke variabler som var forskjellige for de med vold og de uten vold. Variabler som var signifikant hyppigere eller lavere hos de med vold enn de uten ble tatt med i logistisk regresjonsanalyse. Voldsutøvelse ble brukt som dikotom avhengig variabel. Korrelasjoner mellom ulike variabler ble testet med Pearson`s r.

Stegvis regresjonsanalyse ble utført på to måter. Først ble potensielle forklaringsvariabler lagt inn enkeltvis (tabell 2). Etterpå ble variablene cannabis, stimulanter, alkohol og TCO «styrt av ytre krefter» og «frykt for at andre vil skade en" lagt inn som parkombinasjoner i hvert steg (tabell 3), i tillegg til diagnosen paranoid psykose. Den parvise innleggingen av variabler ble gjort for bedre å korrigere for at flere av pasientene var fordelt på flere rus- og symptomvariabler samtidig. Man kunne dermed bedre identifisere eventuelle differanser mellom variablenes enkeltstående og kombinerte effekt på voldsutøvelse.

Signifikanskravet ble satt til 5 prosent, og konfidensintervaller med 95 prosent sannsynlighet for riktig oddsratio ble brukt. P-verdier mellom 0,05 og 0,10 ble vurdert som en statistisk tendens (trend). Vi brukte Cox Snell R Square og Nagelkerke for estimering av forklart varians $\mathrm{i}$ modellene. Alle analysene ble gjennomført i SPSS versjon 18.

\section{RESULTATER \\ Enkeltvariabler knyttet til vold}

I utvalget var det 47 pasienter som utøvde vold i løpet av de fem siste årene før siste innleggelse. Ofre for volden var 35 familiemedlemmer eller andre i nære relasjoner og 21 var ukjente personer. Fem pasienter hadde utøvd planlagt vold som en del av gjengvirksomhet eller organisert kriminalitet.

Tabell 1 viser forekomsten av rusbruk, diagnoser og TCOsymptomer hos undergruppen som hadde utøvd vold og de uten voldsutøvelse. Alle de fire rusmidlene som ble undersøkt, så vel som forekomsten av paranoid psykose og to av tre TCOsymptomer, forekom signifikant oftere blant voldsutøverne, se tabell 1.

De fleste av pasientene brukte flere rusmidler samtidig. Blant 51 pasienter som brukte cannabis, brukte 37 også stimulanter 
$(\mathrm{r}=0,73, \mathrm{p}<0,001)$ mens 25 også brukte alkohol $(\mathrm{r}=0,24, \mathrm{p}$ $=0,004)$. Det var også en signifikant sammenheng mellom bruk av opioider og cannabis $(r=0,41$, ikke signifikant når cannabis ble introdusert i steg 2 (tabell 2). Opioider var ikke signifikant i noen steg. Alkohol og cannabis var signifikante $i$ alle stegene.

\section{De fleste av pasientene brukte flere rusmidler samtidig.}

$\mathrm{p}<0,001)$; cannabisbruk forekom hos alle de 12 pasientene med opioidbruk. Alkohol og stimulantbruk var også overlappende $(r=0,23, p=0,005)$, og bruk av stimulanter forekom hos 21 av 49 pasienter som brukte alkohol.

Pasientene hadde flere diagnoser/symptomer samtidig. Av de 18 med TCO «styrt av ytre krefter", hadde 14 også TCO "andre vil skade en" $(r=0,42, p$ $<0,001)$ og 12 hadde paranoid psykose $(\mathrm{r}=0,32, \mathrm{p}<0,001)$.

\section{Multivariat analyse}

Stimulanter var signifikant assosiert med vold i første steg av regresjonsanalysen, men var
Av diagnose eller symptomer var kun TCO «styrt av ytre krefter» signifikant (tabell 2). Ved bruk av parete variabler (tabell 3) var stimulanter i par med henholdsvis alkohol og cannabis signifikant knyttet til økt vold, men disse kombinasjonene var ikke signifikante når alkohol og cannabis ble introdusert som par. Dette paret forble signifikant i alle steg. TCO «styrt av ytre krefter» og TCO «frykt for at andre vil skade en» i par var signifikant. De uavhengige variablene $\mathrm{i}$ de multivariate analysene forklarte henholdsvis 82,2 prosent (tabell 2) og 80,1 prosent (tabell 3) av variasjonen i voldsforekomst.

Tabell 1: Fordeling og forskjeller mellom gruppene med ( $n=47)$ og uten (n=99) voldsatferd når det gjelder rusbruk, diagnose og TCO-symptomer

\begin{tabular}{llll}
\hline Variabler & $\begin{array}{l}\text { Voldsutøver } \\
\text { gruppe }\end{array}$ & $\begin{array}{l}\text { Ikke volds- } \\
\text { utøver gruppe }\end{array}$ & $\begin{array}{l}\text { Pearson } \\
\text { Kji-kvadrat test }\end{array}$ \\
Cannabis & $33(70,2 \%)$ & $18(18,2 \%)$ & $x 2=37,9, p<0,001$ \\
Alkohol & $29(61,7 \%)$ & $20(20,2 \%)$ & $x 2=24,6, p<0,001$ \\
Stimulanter & $27(57,4 \%)$ & $14(14,1 \%)$ & $x 2=29,5, p<0,001$ \\
Opioider & $10(21,3 \%)$ & $2(2,0 \%)$ & $x 2=15,6, p<0,001$ \\
Paranoid psykose & $21(44,7 \%)$ & $20(20,2 \%)$ & $x 2=9,4, p=0,002$ \\
TCO «styrt ytre krefter» & $12(25,5 \%)$ & $6(6,1 \%)$ & $x 2=11,1, p<0,001$ \\
TCO «andre vil skade» & $23(48,9 \%)$ & $18(18,2 \%)$ & $x 2=14,9, p<0,001$ \\
TC0 «tanker plassert» & $8(17,0 \%)$ & $8(8,1 \%)$ & $P<0,106$ (ikke sign.) \\
Ikke-paranoid psykose & $18(38,3 \%)$ & $28(28,3 \%)$ & $P<0,224$ (ikke sign.) \\
Personlighetsforstyrrelse & $15(31,9 \%)$ & $19(19,2 \%)$ & $P<0,089$ (ikke sign.) \\
Bipolar- mani & $5(10,6 \%)$ & $18(18,2 \%)$ & $P<0,242$ (ikke sign.) \\
\hline
\end{tabular}

\section{DISKUSJON}

Vi fant at bruk av cannabis var sterkest knyttet til voldsutøvelse, tett fulgt av stimulantbruk og alkohol. Også kombinert bruk av cannabis og alkohol hadde en sterk effekt på vold. Alkohol og cannabis så i liten grad ut til å påvirke hverandres effekt på voldsutøvelse og av disse to ble alkohol i minst grad påvirket av andre variabler. Sammenhengen mellom stimulantbruk og voldsutøvelse ble svekket ved samtidig bruk av cannabis og alkohol. Resultatene indikerer samtidig en økt voldsrisiko når TCOsymptomet «å føle seg styrt av ytre krefter» forekom i kombinasjon med bruken av cannabis og alkohol. Dette peker i retning av at TCO-symptomet forsterker sammenhengen mellom cannabis og alkohol og voldsrisiko. En økt voldsrisiko ved alkoholbruk hos mennesker med psykoselidelser er i tråd med tidligere funn $(3,16,23)$.

Våre funn indikerte at opioider var en signifikant faktor for voldsutøvelse, men tabell 2 viser at hvis en allerede bruker cannabis eller alkohol så blir en ikke mer voldelig av å bruke opioider i tillegg. En mulig forklaring er at alle opiatbrukerne $i$ vår studie også brukte cannabis, og nesten alle også alkohol og stimulanter. Drøftingen av funnene i en norsk studie (19) antyder at voldsbruk blant opiatmisbrukere kan ha sammenheng med høyt tilleggsbruk av andre rusmidler, og særlig stimulanter.

Videre fant vi at bruk av stimulanter isolert sett var en signifikant faktor for voldsutøvelse, men heller ikke stimulanter vil påvirke voldsutøvelse ytterligere ved allerede bruk av cannabis og alkohol. Resultatene kan peke i retning av at årsaken til at stimulantbruk har blitt assosiert 
med voldsutøvelse i tidligere studier er at disse pasientene også ofte bruker cannabis og/ eller alkohol - som kanskje er de mest voldsfremmende rusmidlene. Dette avviker til dels fra noen tidligere forsknings- funn, men støttes av resultater fra to metastudier. Tyner \& Fremouw (12) konkluderte med at en sammenheng mellom metamfetamin og vold så ut til å være indirekte og korrelasjonell. Boles \& Miotto (17) vektla at en slik sammenheng er kompleks og påvirket av faktorer hos både individet og omgivelsene rundt. I vår studie var det imidlertid få pasienter som brukte stimulanter alene, uten samtidig bruk av andre rusmidler. Dette kan ha

Tabell 2: Stegvis binær regresjonsanalyse for effekten av rusmidler, diagnose og TCO-symptomer på voldsatferd (n=146).

\begin{tabular}{|c|c|c|c|c|c|c|c|c|}
\hline & $\mathrm{n}$ & Steg 1 & Steg 2 & Steg 3 & Steg 4 & Steg 5 & Steg 6 & Steg 7 \\
\hline & \multicolumn{8}{|c|}{ Oddsratio $(95 \% \mathrm{CI}) \mathrm{P}$ verdi } \\
\hline Stimulanter & 41 & $\begin{array}{l}8,1^{\mathrm{a}} \\
(3,6-18,4)\end{array}$ & 2,2 is & 2,0 is & 1,7 is & 1,3 is & 1,2 is & 1,2 is \\
\hline Cannabis & 51 & - & $\begin{array}{l}6,2^{\mathrm{a}} \\
(2,1-18,0)\end{array}$ & $\begin{array}{l}6,1^{\mathrm{b}} \\
1,9-19,4)\end{array}$ & $\begin{array}{l}5,5^{c} \\
(1,7-18,0)\end{array}$ & $\begin{array}{l}5,5^{d} \\
(1,6-18,3)\end{array}$ & $\begin{array}{l}5,2^{e} \\
(1,6-17,5)\end{array}$ & $\begin{array}{l}6,7^{b} \\
(1,9-23,0)\end{array}$ \\
\hline Alkohol & 49 & - & - & $\begin{array}{l}5,5^{\mathrm{a}}(2,3- \\
13,5)\end{array}$ & $\begin{array}{l}5,5^{\mathrm{a}}(2,2- \\
13,5)\end{array}$ & $\begin{array}{l}5,6^{\mathrm{a}}(2,2- \\
13,8)\end{array}$ & $\begin{array}{l}5,8^{\mathrm{a}}(2,3- \\
14,6)\end{array}$ & $\begin{array}{l}6,4^{\mathrm{a}} \\
(2,4-17,0)\end{array}$ \\
\hline Opioider & 12 & - & - & - & 2,8 is & 2,9 is & 3,0 is & 2,9 is \\
\hline Paranoid psykose & 41 & - & - & - & - & & & \\
\hline TCO «andre vil skade» & 41 & - & - & - & - & - & 2,4 is & 1,8 is \\
\hline $\begin{array}{l}\text { TCO «styrt av ytre } \\
\text { krefter» }\end{array}$ & 18 & - & - & - & - & - & - & $\begin{array}{l}5,3^{f} \\
(1,1-25,3)\end{array}$ \\
\hline Konstant & & $0,235^{\mathrm{a}}$ & $0,165^{\mathrm{a}}$ & $0,087^{a}$ & $0,088^{a}$ & $0,079^{a}$ & $0,064^{a}$ & $0,055^{a}$ \\
\hline \multirow[t]{2}{*}{ Nagelkerke } & & $\begin{array}{l}0,178 \\
0,248\end{array}$ & $\begin{array}{l}0,239 \\
0,334\end{array}$ & $\begin{array}{l}0,315 \\
0,440\end{array}$ & $\begin{array}{l}0,322 \\
0,450\end{array}$ & $\begin{array}{l}0,329 \\
0,459\end{array}$ & $\begin{array}{l}0,343 \\
0,480\end{array}$ & $\begin{array}{l}0,364 \\
0,509\end{array}$ \\
\hline & \multicolumn{8}{|c|}{${ }^{\mathrm{a}} p<0,001,{ }^{\mathrm{b}} p=0,002,{ }^{\mathrm{c}} p=0,004{ }^{\mathrm{d}} p=0,005,{ }^{\mathrm{e}} p=0,006,{ }^{f} p=0,033$, is = ikke signifikant } \\
\hline
\end{tabular}

Tabell 3: Stegvis binær regresjonsanalyse med parvise variabler. Effekt av parkombinasjoner av rusmidler, diagnoser og TCO-symptomer på vold ( $n=146)$.

\begin{tabular}{|c|c|c|c|c|c|c|}
\hline & $\mathrm{n}$ & Steg 1 & Steg 2 & Steg 3 & Steg 4 & Steg 5 \\
\hline & \multicolumn{6}{|c|}{ Oddsratio $(95 \%$ Cl) p verdi } \\
\hline Cannabis og stimulanter & 37 & $3,8^{\mathrm{a}}(2,4-6,0)$ & $1,8^{9}(1,0-3,4)$ & 1,4 is & 1,3 is & 1,2 is \\
\hline Alkohol og Stimulanter & 21 & $3,7^{b}(1,6-8,4)$ & 1,3 is & 1,2 is & 1,1 is & \\
\hline Cannabis og Alkohol & 25 & - & - & $4,1^{\dagger}(1,2-13,3)$ & $4,5^{e}(1,3-15,0)$ & $5,2^{c}(1,5-17,7)$ \\
\hline Paranoid diagnose & 41 & - & - & - & 1,8 is & 1,2 is \\
\hline $\begin{array}{l}\text { TCO «styrt» og «andre } \\
\text { skade» }\end{array}$ & 45 & - & - & - & - & $2,6^{d}(1,2-5,4)$ \\
\hline Konstant & & $0,173^{a}$ & $0,116^{\text {a }}$ & $0,087^{a}$ & $0,078^{a}$ & $0,056^{\mathrm{a}}$ \\
\hline \multirow[t]{2}{*}{ Nagelkerke } & & $\begin{array}{l}0,234 \\
0,327\end{array}$ & $\begin{array}{l}0,286 \\
0,400\end{array}$ & $\begin{array}{l}0,315 \\
0,440\end{array}$ & $\begin{array}{l}0,321 \\
0,449\end{array}$ & $\begin{array}{l}0,353 \\
0,493\end{array}$ \\
\hline & \multicolumn{6}{|c|}{${ }^{\mathrm{a}} p<0,001,{ }^{\mathrm{b}} p=0,002,{ }^{\mathrm{c}} p=0,008,{ }^{d} p=0,009,{ }^{\mathrm{e}} p=0,014,{ }^{\mathrm{d}} p=0,018,{ }^{9} p=0,049$, is $=$ ikke signifikant } \\
\hline
\end{tabular}


begrenset studiens mulighet til å identifisere en spesifikk effekt av stimulantbruk.

Funnene vedrørende cannabisbruk er overraskende og åpner for spørsmål rundt effekten av cannabis på mennesker med alvorlig psykisk lidelse. Vi kjenner ikke til studier som spesifikt undersøker sammenhengen mellom cannabisbruk, utvikling av forfølgelsesvrangforestillinger som for eksempel TCO-symptomer og voldsatferd. Våre funn indikerer at dette er et forskningsområde som bør prioriteres. Studiens følgelsesideer (24). Visse typer cannabis kan være et potent rusmiddel som influerer plagsomme symptomer med påfølgende emosjonelt stress og kanskje voldsutøvelse hos sårbare individer.

TCO-symptomet «styrt av ytre krefter» var en signifikant prediktor for voldsutøvelse i vår studie, også når vi kontrollerte for effekten av rusmidler. Funnet støttes av andre studier, som Hodgins \& Riaz (5) som fant at slike symptomer var assosiert med vold selv ved kontroll for rusbruk. I denne studien økte

\section{Vi fant at bruk av cannabis var sterkest knyttet til voldsutovelse, tett fulgt av stimulantbruk og alkohol.}

design tillot ikke å kontrollere for andre bakenforliggende faktorer som kunne påvirke assosiasjonen mellom cannabis og risiko for voldsutøvelse. Funnet bør likevel vurderes i lys av at studien er utført blant individer med hyppige eller lengre innleggelser i psykiatrisk sykehus og interaksjon mellom cannabis og alvorlige psykiske lidelser. Som anført for alkohol og stimulanter kan mennesker med alvorlige psykiske lidelser være mer sårbare for virkningen av rusmidler. Dette kan også skyldes lidelsestilknyttede faktorer som endret kognitiv funksjon, psykososial belastningshistorie, nåværende forhold som sosial isolasjon og eventuelle biogenetiske faktorer. Et annet aspekt er at selv om cannabis gjerne vurderes som et dempende rusmiddel, har det også hallusinogene effekter. Særlig er det mulig at $ø$ kt innhold av virkestoffet tetrahydrocannabinol (THC) i nyere former for cannabis kan gi brukeren sekvenser av forvrengt virkelighetsoppfatning med for- risikoen for aggressiv atferd 2,8 ganger for hvert TCO-symptom. van Dongen og medarbeidere (10) fant at TCO-symptomer kan utløse frykt og stress hos individer med psykoser, som igjen kan øke voldsrisiko. I tillegg ga tilstedeværelse av TCO en økt risiko for voldsutøvelse hos dem som brukte alkohol og cannabis.

Et viktig funn var at diagnosen paranoid psykose ikke var signifikant i regresjonsanalysene. I tillegg gikk oddsratioen for denne diagnosen videre ned når spesifikke TCO-symptomer ble tatt med i analysene. Selv om paranoid psykose var signifikant i korrelasjonsanalysen, kan vi på grunnlag av regresjonsanalysene anta at diagnoser som schizofreni og paranoid psykose ikke alene kan forklare voldelig atferd. På den annen side kan disse diagnosene innebære at pasienten også har mer potente TCO-symptomer. Kartlegging av spesifikke symptomer og bruk av rusmidler kan dermed ha betyd- ning for behandling og forløp for denne pasientgruppen.

\section{Begrensninger}

En mulig svakhet er at mange av pasientene i studien var fordelt på flere diagnoser og symptomer og at de samtidig brukte flere typer rusmidler. Dette kan ha påvirket karakteristika som var assosiert med voldsutøvelse. Vi vet ikke i hvilken grad pasientene var ruspåvirket, og eventuelt av hvilke rusmidler, da de gjennomførte voldshandlingene. Det kan være at vi ikke bare fanger opp effekter av aktiv rus, men også effekter av abstinens og følelsesmessige reaksjoner over tid ved bruk av rusmidler i denne pasientgruppen. Abstinens i forbindelse med bruk av cannabis kjennetegnes ofte av irritasjon, søvnløshet og nedstemthet (24).

Det kan også ha påvirket funnene at studien er en ikkeeksperimentell assosiasjonsstudie/tverrsnittsstudie uten kontrollgruppe. Videre kan svakheter ved datainnsamlingen gjøre at funnene må tolkes med forsiktighet fordi data om vold og rusbruk var samlet inn over flere år og av forskjellige aktører (15). Designen gir dermed ikke grunnlag for å trekke sikre kausale slutninger.

En prospektiv studie vil kunne kontrollere bedre for andre mulige påvirkningsvariabler og sosiale faktorer som sysselsetting, boforhold, familieforhold og skole eller utdanning. Videre bør det kontrolleres spesifikt for atferds- og personlighetsfaktorer som antisosial personlighetsforstyrrelse og tidligere voldshistorie $(11,12)$. For bruk av spesielt alkohol og cannabis bør det kontrolleres bedre for situasjon og frekvens ved bruk i forhold til TCO-symptomer og voldsutøvelse. 


\section{KONKLUSJON}

Studien indikerer at bruk av rusmidlene alkohol og cannabis hver for seg og i kombinasjon kan øke risikoen for voldsutøvelse hos pasienter med utstrakt innleggelsesbehov i psykisk helsevern. I tillegg økte voldsrisikoen ved positive psykosesymptomer, som det å føle seg kontrollert av ytre krefter, både alene og i samspill med samtidig bruk av alkohol og cannabis. Betydningen av spesielt cannabisbruk hos denne pasientgruppen bør undersøkes nærmere med prospektive design.

Funnene tilsier at behandlere, sykepleiere og andre hjelpere ikke bør undervurdere effekten av bruk av alkohol og cannabis på voldsrisiko hos pasienter, spesielt ved samtidig forekommende TCO-symptomer. Hos pasienter som klinisk presenterer flere av eller alle disse faktorene eller symptomene, bør strukturerte voldsrisikoinstrumenter brukes som en del av utredning før behandling.

\section{REFERANSER}

1. Fazel S, Grann M. The population impact of severe mental illness on violent crime. Am J Psychiatry 2006;163:8. 2. Douglas K, Guy L, Hart S. Psychosis as a risk factor for violence to others: a meta-analysis. Psychological Bulletin 2009;135:679-706.

3. Elbogen Eric B, Johnson Sally C. The intricate link between violence and mental disorder. Results from the national epidemiologic survey on alcohol and related conditions. Arch Gen Psychiatry 2009;66:152-61

4. Fazel S, Lichtenstein P, Grann M, Goodwin GM, Långstrøm N. Bipolar disorder and violent crime. New evidence from population-based longitudinal studies and systematic review. Arch Gen Psychiatry 2010;67:931-8.

5. Angermeyer MC. Schizophrenia and violence. [Review]. Acta Psychiatrica Scandinavica, Supplementum 2000;407:63-7.

6. Hodgins S, Riaz M. Violence and phases of illness: Differential risk and predictors. European Psychiatry 2011;26:518-24

7. Bo S, Ahmad A, Kongerslev M, Haahr UH, Simonsen E. Risk factors for violence among patients with schizophrenia. Clinical Psychology Review 2011;31:711-26. 8. van Dongen JDM, Buck NML, van Marle HJC. Persecutory ideations indirectly effect inpatient aggression through delusional distress. Psychiatry Research 2012;05-16.

9. Link BG, Stueve A, Phelan J. Psychotic symptoms and violent behaviors: probing the components of "threat/control-override" symptoms. Social Psychiatry and Psychiatric Epidemiology 1998;1:55-60
10. Link BG, Steuve A. Psychotic symptoms and the violent/illegal behavior of mental patients compared to community controls. Violence and mental Disorder 1994;137-60.

11. Macdonald S, Erichson P, Wells $S$, Hathaway A, Pakula B. Predicting violence among cocaine, cannabis, and alcohol treatment clients. Addictive Behaviors 2008;33:201-5

12. Tyner EA, Fremouw WJ. The relation of methamphetamine use and violence: A critical review. Aggression and violent behavior 2008;13:285-97.

13. Volavka J. The effects of clozapine on aggression and substance abuse in schizophrenic patients [review]. Journal of Clinical Psychiatry 1999;12:43-6.

14. Latt N, Jurd S, Tennant C, Lewis J, Macken L, Joseph A, Grochulski A, Long L. Alcohol and substance use by patients with psychosis presenting to an emergency department: changing patterns. Australasian Psychiatry 2011;19:354-9. 15. Fosse R, Olsen BM, Bjørkly S. Violence in acute psychiatric patients: a cumulative increased risk with polysubstance abuse? International journal of forensic mental health services 2013;12:165-71.

16. Steadman Henry, Mulvey Edward, Monahan John, Robbins Pamela, Appelbaum Paul, Grisso Thomas, Roth Loren, Silver Eric. Violence by people discharged from acute psychiatric inpatient facilities and by others in the same neighborhoods. Arch Gen Psychiatry 1998;55:393-401.

17. Boles Sharon, Miotto Karen. Substance abuse and violence: A review of the literature. Aggression and violent behavior 2003;2:155-74
18. Gmel Gerhard, Rehm Jürgen. Harmful Alcohol Use. National institute on alcohol abuse and alcoholism 2003. Tilgjengelig fra: http://www. niaaa.nih.gov/

19. Havnes I, Bukten A, Gossip M, Waal $\mathrm{H}$, Stangeland P, Clausen T. Reductions in convictions for violent crime during opioid treatment: A longitudinal national cohort study. Drug and Alcohol Dependence 2012;124:307-10.

20. Saunders JB, Aasland OG, Babor TF, De La Fuenta JR, Grant M. Development of the alcohol use disorders identification test (AUDIT): WHO collaborative project on early detection of persons with harmful alcohol consumption 2. Addiction 1993; 88:784--91

21. Berman AH, Bergman H, Palmstierna T, Schlyter F. Evaluation of the drug use disorder identification test (DUDIT) in criminal justice and detoxification settings and in a Swedish population sample. European addiction research 2005 . 11:22-31

22. Hartvig $P$, Østberg B, Alfarnes SA, Moger TA, Skjønsberg M, Bjørkly S. Violence Risk Screening-10. Centre for Research and Education in Forensic Psychiatry. Oslo 2007.

23. Rasanen $\mathrm{P}$, Tiihonen J, Isohanni M, Rantakallio P, Lehtonen J, Moring J. Schizophrenia, alcohol abuse, and violent behavior: A 26-year follow up study of an unselected birth cohort. Schizophr Bull 1998; 24: 437-41.

24. Folkehelseinstituttet. Divisjon for rettstoksikologi og rusmiddelforskning. Fakta om amfetamin og metamfetamin. Fakta om cannabis, hasjisj og marihuana. 2012. Tilgjengelig fra: http:// www. fhi. no/artikler/?id=47081 